\title{
BIOGAS PRODUCTION FROM SUGAR CANE PRESS MUD AND SUGAR CANE BAGASSE BY ANAEROBIC CO-DIGESTION
}

\author{
S J Malik \\ Pune, Maharashtra, India
}

Abstract - The result of this research is to determine the ratio of the combination (co-digestion) of Press Mud and Bagasse to the volume of biogas production, and for the bagasse as a single substrate. Samples were tested and used without any pre-treatment. Biogas production volume and the effect of co-digestion on biogas production are discussed further in the paper. The results showed that the digester with $9 \%$ total solids when fed considering only bagasse as a single feedstock gave good amount of biogas compared to $6 \%$ or $12 \%$ total solid. The study also investigates the different factors which affected the biogas generation from sugar industry waste bagasse. In this paper, sugarcane bagasse was used as a feedstock for biogas generation in an anaerobic type lab scale digester similarly a co digestion of bagasse and press mud was also observed. Inoculum from cow dung was used in the above experiments. The anaerobic digestion as well as the co digestion was carried out in batch mode with mesophilic temperature of $35^{\circ} \mathrm{C}$ and 50 days of hydraulic retention time. The cumulative gas production achieved for both (only bagasse digestion and co-digestion of press mud and bagasse) is explained further in this paper. Temperature, pH, biogas flow etc was measured using respective meters. Bagasse is one of the suitable wastes for biogas generation through anaerobic digestion. And without any doubt bagasse and press mud can also be used together in co digestion process to see enhanced gas generation and organic manure generation from the experiments.

Keywords - Anaerobic Digestion, Biogas, Bagasse, Press Mud

\section{INTRODUCTION}

The production of biogas from renewable energy sources has become essential due to the increasing demand for energy and the need for reduction in greenhouse gas emissions. This research focuses on biogas extraction from bagasse separately and co digestion of bagasse and press mud. In various nations including India, bagasse from sugarcane accounts for the largest proportion of industrial waste. It can be used for biofuel production. Sugarcane bagasse is a lignocellulosic residue. Bagasse is used as fuel in boilers to produce low pressure steam. However, there is still surplus bagasse that can lead environmental and storage issues.

Various types of fuels may be produced through thermochemical or bio-chemical processes from the lignocellulosic wastes. Anaerobic digestion processes many kinds of wastes

\author{
Srinivas Kasulla \\ Hyderabad, Telangana, India
}

and produces biogas. It, primarily consisting of methane and carbon dioxide, is considered as a clean and renewable energy source. Anaerobic digestion is regarded as one of the most effective process because it allows for power generation and has environmental advantages. Anaerobic digestion is a biochemical process for the treatment of organic substrates such as sewage and industrial effluents, animal manures and solid substrates (energy crops, agricultural residues, food wastes, etc.). It involves the series of biological process in which microorganism breaks down complex organic matter leading to an energy-rich biogas which can be used as renewable energy to replace fossil energy sources. After pre-treatment of the substrate, the bio-digestion would increase and enhance the biogas production. Various pre-treatment techniques, including biological, chemical or physical procedures or their combinations, have been researched based upon the lignocellulosic feedstock. Degradation compounds like formic acid, acetic acid, levulin, furan derivatives, etc. are frequently used in pre-treatment. They are normally organic acids. Heat, dilute acid, dilute alkaline and oxidative treatments are also researched. The kinetic determination of the biogas generation provides important statistics on the biodegradability of the pre-treated substrates. It also determines whether hydrolysis is a limiting stage. Thus, the objective of this study is to assess the impact of certain process parameters on the production of biogas from sugar cane bagasse as a separate experiment and co digestion of sugar cane bagasse and press mud the other.

\section{EXPERIMENT}

The characterization of the bagasse was carried out by performing proximate as well as ultimate analysis. Determination of chemical oxygen demand, calorific value of the bagasse was also performed in the biomass to check its potentiality for biogas production. Since literature on biogas production from most of the samples collected for bagasse are hardly found, biogas production from fresh cow manure was also examined to compare the results with that of the bagasse and press mud. The characterization of the substrates included the determination of the following below mentioned parameters.

1. Moisture content

2. Volatile Matter content

3. Ash content

4. Total Solid content

5. Fixed carbon

6. Lignin 
7. Cellulose

8. Hemicellulose

9. Elemental analysis

10. Chemical Oxygen Demand

Table -1

\begin{tabular}{|c|c|c|c|c|c|c|}
\hline Parameter & S-1 & S-2 & S-3 & S-4 & S-5 & S-6 \\
\hline Moisture C & 13 & 12 & 13 & 11.5 & 11.5 & 12 \\
\hline Volatile M \% & 85 & 84.5 & 84 & 83 & 85.5 & 84.3 \\
\hline Ash C \% & 2 & 1.9 & 2.1 & 2 & 1.9 & 2 \\
\hline Total Solid C & 87 & 88 & 87 & 88.5 & 88.5 & 88 \\
\hline $\begin{array}{c}\text { Fixed Carbon } \\
\text { C \% }\end{array}$ & 12 & 11.5 & 11.3 & 11 & 11 & 11.5 \\
\hline $\begin{array}{c}\text { Cellulose \% } \\
\text { Hemicellulose }\end{array}$ & 32 & 34 & 31 & 30 & 32 & 32 \\
\hline $\begin{array}{c}\text { Lignin C \% } \\
\text { Calorific Val } \\
\text { (MJ/kg) }\end{array}$ & 18 & 16 & 18 & 16 & 18 & 18 \\
\hline C.O.D. (mg/l) & 3425 & 3605 & 3160 & 3320 & 2890 & 3680 \\
\hline
\end{tabular}

Ultimate Analysis

Table -2

\begin{tabular}{|c|c|c|c|c|c|c|}
\hline UA & S-1 & S-2 & S-3 & S-4 & S-5 & S-6 \\
\hline $\begin{array}{c}\text { Carbon } \\
\%\end{array}$ & 50.45 & 49.50 & 50.10 & 48.80 & 49.9 & 48.50 \\
\hline $\begin{array}{c}\text { Nitrogen } \\
\%\end{array}$ & 0.81 & 0.80 & 0.83 & 0.85 & 0.88 & 0.79 \\
\hline $\begin{array}{c}\text { Oxygen } \\
\%\end{array}$ & 49.44 & 48.36 & 46.75 & 47.50 & 49.63 & 49.73 \\
\hline
\end{tabular}

Table -3

$\mathrm{C}: \mathrm{N}$ ratio of Bagasse before and after mixing with Cow Manure in the ratio 1:3

\begin{tabular}{|c|c|c|c|c|c|c|}
\hline & S-1 & S-2 & S-3 & S-4 & S-5 & S-6 \\
\hline $\begin{array}{c}\text { Carbon } \\
\%\end{array}$ & 50.45 & 49.50 & 50.10 & 48.80 & 49.9 & 48.50 \\
\hline $\begin{array}{c}\text { Nitroge } \\
\text { n \% }\end{array}$ & 0.81 & 0.80 & 0.83 & 0.85 & 0.88 & 0.79 \\
\hline C:N & $\begin{array}{c}62.28: \\
1\end{array}$ & $\begin{array}{c}61.87: \\
1\end{array}$ & $\begin{array}{c}60.36: \\
1\end{array}$ & $\begin{array}{c}57.41: \\
1\end{array}$ & $\begin{array}{c}56.70: \\
1\end{array}$ & $\begin{array}{c}61.39: \\
1\end{array}$ \\
\hline $\begin{array}{c}\text { C:N } \\
\text { (Bagass }\end{array}$ & $28.4: 1$ \\
$\begin{array}{c}\text { e + Cow } \\
\text { manure } \\
-1: 3\end{array}$ & $\begin{array}{c}30.1: 1 \\
-\end{array}$ & $\begin{array}{c}27.8: 1 \\
-\end{array}$ & $\begin{array}{c}27.4: 1 \\
-\end{array}$ & $\begin{array}{c}26.6: 1 \\
-\end{array}$ & $\begin{array}{c}26.5: 1 \\
-\end{array}$ & $\begin{array}{c}27.6: 1 \\
-\end{array}$ \\
\hline
\end{tabular}

While feeding to the digester different samples were fed between $10-11 \%$ Total solid content entering the digester and this was adjusted with the help of fresh water. Bagasse was fed to the lab scale digester with slight reduction in the particle size manually. 50 days retention time was calculated, and biogas generation was observed on daily basis until the biogas production started reducing significantly. The daily volume of biogas produced during the entire experiment was measured using water displacement system under ambient conditions. Brine solution was used in the water displacement method to avid absorption of $\mathrm{CO}_{2}$ by water during the biogas measurement. It is prepared by adding $\mathrm{NaCl}$ to water until a supersaturated solution s formed. A few drops of concentrated $\mathrm{H}_{2} \mathrm{SO}_{4}$ are added to the solution to make the brine solution acidic. The solution bottle containing brine solution is fitted to the reactor through connecting pipe. When biogas production started in the digester it is transferred to the solution bottle containing acidified brine solution through the connecting tube and applies pressure into the solution. As a result, the solution comes out through the outlet opening and gets poured into the measuring beaker. The amount of solution in the beaker indicates the amount of biogas production.

Effect of Total Solids on Biogas production from untreated bagasse along with cow manure was observed for 50 days HRT and noted down in the table:

Table -4

\begin{tabular}{|c|c|}
\hline Total Solids & Biogas production \\
\hline TS $12 \%$ & $620 \mathrm{ml}$ \\
\hline TS $9 \%$ & $710 \mathrm{ml}$ \\
\hline TS $6 \%$ & $540 \mathrm{ml}$ \\
\hline
\end{tabular}

After understanding the behavior of Bagasse in the digester a separate experiment with co-digestion of Bagasse with press mud was carried out. Digester was added with bagasse, press mud and cow manure.

Table -5

\begin{tabular}{|c|c|c|}
\hline Sr.No. & Parameters & Press mud \\
\hline 1 & Moisture Content & $10 \%$ \\
\hline 2 & Total Solids & $90 \%$ \\
\hline 3 & Total Minerals & $16 \%$ \\
\hline 4 & Organic Carbon & $47 \%$ \\
\hline 5 & Organic Matter & $81 \%$ \\
\hline
\end{tabular}




\begin{tabular}{|c|c|c|}
\hline 6 & C:N & 17.7 \\
\hline 7 & Crude Fibre & $22 \%$ \\
\hline 8 & Bulk Density & $0.28 \mathrm{~kg} / \mathrm{m} 3$ \\
\hline 9 & Lignin & $19 \%$ \\
\hline 10 & Hemicellulose & $15 \%$ \\
\hline 11 & Cellulose & $27 \%$ \\
\hline
\end{tabular}

Table no 6 shows the biogas production from bagasse and pressmud mixed together and similarly 6 experiments were carried out like it was done earlier only for bagasse.

Table -6

\begin{tabular}{|c|c|c|c|c|c|c|c|}
\hline No & Details & S-1 & S-2 & S-3 & S-4 & S-5 & S-6 \\
\hline 1 & $\begin{array}{c}\text { Bagasse } \\
\text { (Gas } \\
\text { Production } \\
\text { L/gm of } \\
\text { TVS) }\end{array}$ & 0.170 & 0.180 & 0.185 & 0.178 & 0.200 & 0.175 \\
\hline 2 & $\begin{array}{c}\% \text { of } \\
\text { Methane }\end{array}$ & $49 \%$ & $51 \%$ & $50 \%$ & $49 \%$ & $52 \%$ & $49 \%$ \\
\hline $\begin{array}{c}\text { Pressmud } \\
\text { and } \\
\text { Bagasse } \\
\text { Gas } \\
\text { Production } \\
\text { L/gm of } \\
\text { TVS) }\end{array}$ & 0.450 & 0.480 & 0.490 & 0.455 & 0.500 & 0.400 \\
\hline 4 & $\begin{array}{c}\% \text { of } \\
\text { Methane }\end{array}$ & $78 \%$ & $76 \%$ & $75 \%$ & $77 \%$ & $76 \%$ & $70 \%$ \\
\hline
\end{tabular}

\section{BIO-METHANATION POTENTIAL AND CONCLUSION}

In the analysis of Bagasse and Press mud it was found that the characterization was carried out by performing proximate analysis, ultimate analysis, determining the chemical oxygen demand, calorific value and by estimating the fibre composition of the substrates. It is observed from the results that bagasse having lignocellulosic percentage has a very high amount of volatile matter content, carbon content and higher calorific value which makes it a potential source of renewable energy. As a result, the fermentation of this substrate takes longer period as compared to press mud. To avoid the delay in hydrolysis process of fermentation, pre-treatment of bagasse is recommended. Pre-treatment generally breaks the lignin part present in bagasse beforehand thus exposing the cellulose part of it which makes it easier for the bacteria to decompose the bagasse effectively this avoiding delay in hydrolysis process.

Bio-methanation Potential of sugarcane bagasse mixed with cow dung was carried out in the first experiment considering 6 different samples from 6 different locations and at 3 different

feed, total solids and the results were presented in the Table 4 It was found that the biogas production at $9 \%$ total solid feed were found to be the highest which was $710 \mathrm{ml}$ compared to the other two feedstock percentages. Further considering the same feedstock total solid content further 6 different experiments were carried out for understanding the biogas production (litre per gm of total volatile solids) and it was found that on an average $0.181 \mathrm{~L} / \mathrm{gm}$ of TVS can be obtained. Similarly, the biogas production from the mixture of press mud along with bagasse and cow manure was carried out for 6 different samples and the average gas production was observed to be $0.462 \mathrm{~L} / \mathrm{gm}$ of TVS. These details were observed when the feedstock total solid percentage was $90 \%$ with almost $10 \%$ moisture levels, further any change in the feedstock total solid content will vary the gas production accordingly. On an average if one assumes a mixture of bagasse with $90 \%$ total solids and press mud with $90 \%$ total solids then the gas production will be approximately $345 \mathrm{~m}^{3}$ per ton of this mixture. Similarly if one assumes a mixture of bagasse with $90 \%$ total solids and press mud with $25 \%$ total solids on fresh basis then the gas production will be approximately $178 \mathrm{~m}^{3}$ per ton of this mixture.

\section{REFERENCE}

1. Masud Hossain SK, N., Ananthraman and Manas Das, 2009. Anaerobic biogas generation from sugar industry waste waters in three - phase fluidized- bioreactor, Indian Journal of Chemical Technology, Vol.16,pp.58-64

2. Agrawal KM, Barve BR and Khan SS. Biogas production from Pressmud at second international conference of emerging trend in engineering, IOSR journal of Mechanical \& Civil engineering (pp. 37-41)

3. Malik SJ, Gunjal BB, Kasulla Srinivas and Gunjal Aparna (April 2019). Spentwash and Pressmud to BioCNG - An Overview at Bioenergy from Sugar Industry - A way forward for sustainability, Nijalingappa Sugar Institute, Belagavi

4. Samuel N. M. de Souza, Reginaldo F. Santos, and Guilherme P. M. Fracaro, 2011. Potential for the production of biogas in alcohol and sugar cane plants for use in urban buses in the Brazil, World renewable energy congress 2011, Sweden, pp 418-424

5. Kasulla Srinivas and S J Malik, "Enhancement in Biogas Production from Press Mud”, Nov 2020. IJEAST Vol 5, Issue 5, pp 213-216

6. Camilo Carnejo and Ann C. Wilkie, 2010. Greenhouse gas emissions and biogas potential from livestock in Ecuador, Energy for sustainable development, 14, pp. 256-266

7. Mohammad J. Taherzadeh and Keikhosro Karimi, 2008. Pretreatment of Lignocellulosic Wastes to Improve Ethanol and Biogas Production: A Review, Int. J. Mol. Sci., 9; DOI: 10.3390/ijms9091621 pp. 1621-1651 
8. Gavrilescu, M. and Chisti, Y. 2005. Biotechnology- a sustainable alternative for chemical industry, Biotechnology Advances, 23, 471-499.

9. Bajpai Pramod and Jotshi Chand (2010). Optimization of Biogas generation from Pressmud in batch reactor at Bangladesh journal of scientific research 45 (4) (pp. 371376)

10. Y. Sun and J. Cheng, "Hydrolysis of lignocellulosic materials for ethanol production: a review," Bioresource technology, vol. 83, pp. 1-11, 2002.

11. W. S. F. Simo, N. E. Jong, and C. Kapseu, "Improving Biogas Production of Sugarcane Bagasse by Hydrothermal Pretreatment," Chemical and Biomolecular Engineering, vol. 1, pp. 21-25, 2016.

12. Ribeiro F. R, F. Passos, L. V. A. Gurgel, B. E. L. Baêta, and S. F. de Aquino, "Anaerobic digestion of hemicellulose hydrolysate produced after hydrothermal pretreatment of sugarcane bagasse in UASB reactor," Science of the Total Environment, vol. 584, pp. 11081113, 2017.

13. L. Janke, A. Leite, M. Nikolausz, T. Schmidt, J. Liebetrau, M. Nelles,2015 et al., "Biogas production from sugarcane waste: assessment on kinetic challenges for process designing," International journal of molecular sciences, vol. 16, pp. 20685-20703

14. Malik S J | Aparna Saraf | Srinivas Kasulla "Biogas Production from Decanter Cake of Palm Oil Mill from South India" Published in International Journal of Trend in Scientific Research and Development (ijtsrd), ISSN: 2456-6470, Volume-5 | Issue-1, December 2020, pp.1144-1147

15. F. Monnet, "An introduction to Anaerobic Digestion of Organic Wastes," 2003.

16. Das M Ghatak and P. Mahanta (2014), " The Effect of Temperature and Total Solid on Biomethanation of Sugarcane Bagasse". The IUP Journal of Mechanical Engineering, Vol.7 (3), pp. 68 - 75. 